\title{
Silisyum Karbür Takviyeli Alüminyum Matrisli Kompozitlerin Tek Aşırı Yükler Altında Yorulma Davranışı
}

\author{
${ }^{* 1}$ Yakup Çam and ${ }^{2}$ Adem Karcı \\ ${ }^{* 1}$ Faculty of Aeronautics and Astronautics, Erciyes University, Turkey \\ ${ }^{2}$ Faculty of Aeronautics and Astronautics, Erciyes University, Turkey
}

\section{Özet}

Seramiklerle güçlendirilmiş metal esaslı malzemeler, ticari metal alaşımlara göre daha yüksek aşınma direnci, rijitlik ve özgül dayanım özelliklerine sahiptir. Yüksek dayanım/ağırlık oranlarından dolayı otomobil ve havacılık endüstrisinde kullanımları artmaktadır. Özellikle uçak yapısal parçaları için bu malzemelerin, hasar tolerans tasarımının bir gereği olarak, yorulma çatlak başlangıcı ve yorulma çatlak ilerleme hızının çok iyi karakterize edilmesi hedeflenmektedir.

$\mathrm{Bu}$ çalışmada, alüminyum $(\mathrm{Al})$ matrisli, silisyum karbür parçacık $\left(\mathrm{SiC}_{\mathrm{p}}\right)$ takviyeli metal matrisli kompozit malzemelerin, sabit genlikli yükleme sırasında uygulanan tek aşırı yükler altındaki yorulma çatlak ilerleme davranışı, yorulma çatlak ilerleme hızı ve etkin çatlak ilerleme mekanizmaları açısından incelenmiştir. Takviyesiz alaşım ve $\% 5 \mathrm{SiC}$ takviyeli kompozit malzemeler toz metalürjisi yöntemi kullanılarak üretilmiş ve ikincil işlem olarak ekstrüzyon uygulanmıştır. Malzemenin mekanik davranışlarını incelemek için çekme ve yorulma testleri yapılmıştır. Tek aşırı yüklerin etkisini incelemek için takviyeli ve takviyesiz malzemeler üzerinde farklı tek aşırı yükler uygulanmıştır. Yorulma çatlağı ilerleme gecikmesi, 1.25-1.75 arasındaki aşırı yük oranı (AYO) değerlerinin tamamında görülmekle birlikte, çatlak ilerleme gecikmesi AYO değerinin artmasıyla artmıştır.

Anahtar Kelimeler: Metal matrisli kompozitler, yorulma davranışı, tek aşırı yükler

\section{Fatigue Crack Behaviour of Silicon Carbide Reinforced Aluminum Matrix Composites Under Single Overloads}

\begin{abstract}
Ceramic reinforced metal based materials have higher wear resistance, stiffness and specific strength than commercial metal alloys. Due to their high strength to weight ratios, their use is increasing in the automobile and aviation industries. In particular, these materials for aircraft structural parts, as a requirement of the damage tolerance design fatigue crack initiation and fatigue crack growth rate is expected to be very well-characterized.

In this study, fatigue crack behavior of a silicon carbide particulate $\left(\mathrm{SiC}_{\mathrm{p}}\right)$ reinforced aluminium $(\mathrm{Al})$ matrix composite materials were investigated in terms of fatigue crack growth rate and effective crack growth mechanisms under single overloads applied during constant amplitude loading. Aluminium alloy without reinforcement and 5\% $\mathrm{SiC}$ reinforced composite materials were produced by using the powder metallurgy method and extrusion was applied as a secondary process. Tension and fatigue tests were carried out to investigate the mechanical behavior of the material produced. To investigate the effect of single overloads, experiments were conducted on reinforced and unreinforced materials at different single overload rates (OLR). Although the fatigue crack growth retardation is observed all of the OLR values between OLR $=1.25-1.75$, the crack growth retardation is increased by the increase of the OLR value.
\end{abstract}

Key words: Metal matrix composites, fatigue behavior, single overloads

*Corresponding author: Address: ${ }^{1}$ Faculty of Aeronautics and Astronautics, Erciyes University, Kayseri, TURKEY

E-mail address: yakupcam@erciyes.edu.tr, Phone: +903522076666-41115 


\section{Giriş}

Günümüzde havacılık ve uzay endüstrileri başta olmak üzere birçok alanda meydana gelen teknolojik gelişmelerden malzeme bilimi de etkilenmiştir. Klasik malzemeler, ortaya çıan teknolojik ihtiyaçlara cevap vermede yetersiz kalmaktadır. Kompozit malzeme, iki veya daha çok sayıdaki aynı veya farklı tür malzemelerin en üstün özelliklerini, yeni bir malzemede toplamak için, mikroskobik seviyede birleşmesiyle oluşturulan malzemelerdir. Bir kompozit malzemenin yapısında genelde düşük modül ve dayanıma sahip matris ile bunun içinde dağılmış daha az oranda kullanılan takviye elemanı bulunmaktadır [1]. Kompozitler oldukça farklı sınıf malzemelerden oluşabilmektedir. Şekil 1'de kompozitlerin üretildiği malzeme sınıfları yer almaktadır.

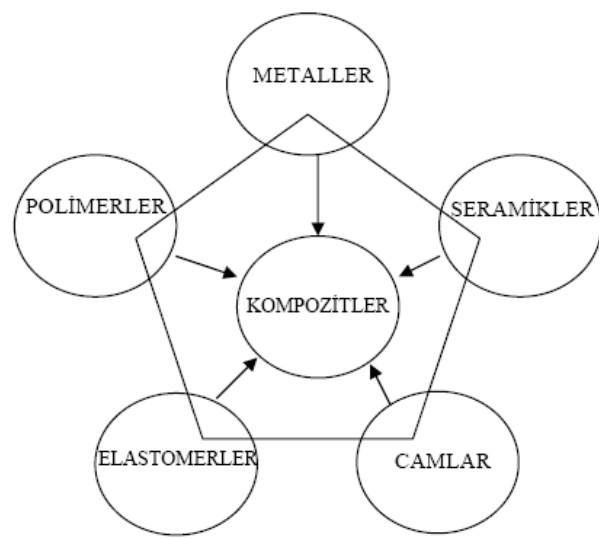

Şekil 1.1 Kompozit Malzemelerin Üretildikleri Malzeme Sınıfları [2]

Kompozit malzemeler yapısal bileşenlerine ve kullanılan matris malzemesine göre sınıflandırılır. Metal matrisli kompozitler takviyesiz metal alaşımlarına göre üstün özelliklere sahiptir. Fiber ve parçacık şeklindeki rijit ve yüksek mukavemetli takviye malzemeleri, geleneksel alaşımlara dayanım, aşınma ve sürünme direnci ve yüksek sıcaklıklara dayanıklılık gibi özellikler katar. Seramiklerin yüksek elastik modül ve metallerin yüksek süneklik özellikleri bu malzemelerde bir araya getirilerek, havacılık ve savunma sanayi yanında otomotiv sektöründe de son yıllarda kullanılmaktadır [3]. Metal matrisli kompozit teknolojisi sürekli gelişmeye devam etmektedir. Cam fiber takviyeli polimer esaslı kompozitler ile karşılaştırıldığında metal matrisli kompozit malzemeler yüksek sıcaklıklardaki çalışma performansları yönünden daha üstündür. Metal matrislerin mukavemeti ve elastik modülü geniş bir sıcaklık aralığında reçine matrisli malzemelerden daha yüksektir [4]. Partikül takviyeli metal matrisli kompozit malzemeler; yüksek elastik modülü ve mukavemeti, yüksek aşınma direnci, üretimleri kolay, çok çeşitli ve düşük maliyetli olarak üretilmeleri sonucu bu konu üzerinde çalışmalarda önemli hale gelmişlerdir. Partikül takviye çeşidinin fazla olması ve üretim yöntemlerinin çok çeşitli olması geniş çalışma alanları sağlamaktadır [5].

MMK lerin mekanik özellikleri takviye hacim oranına bağlı olarak değişmektedir. Metal matrisin cinsi, takviye elemanının cinsi, şekli, boyutu, homojen dağılımı, tercih edilen imalat yöntemi ve işlemler malzemenin mekanik özelliklerini belirleyen diğer etkenlerdir. Parçacık metal matrisli kompozitlerde $\mathrm{SiC}, \mathrm{Al2O}$, TiC, zirkon, silika, bor karbür gibi sert parçacıklar alüminyum alaşımlarının abrasive aşınma direncini önemli derecede geliştirirken, grafit ve mika gibi yumuşak 
katı yağlayıcı parçacıklar alüminyum alaşımlarının yapışma direncini geliştirmektedir [4]. Bir diğer önemli mekanik özellik ise elastik modülüdür. Elastisite modülünün belirlenmesinde etkin olan faktör, takviye malzemesinin hacim oranıdır. Al-SiC gibi parçacık takviyeli kompozitlerde takviyesiz alüminyuma göre elastisite modülü değerlerinde \%50-100 artış sağlanabilmektedir [6, 7]. Bir diğer mekanik özellik olan kırılma tokluğu değeri ise, çatlak oluşumuna ve ilerlemesine karşı direncin bir göstergesi olarak ifade edilmektedir. Yüzde uzama değeri fazla olan, yani plastik deformasyon kabiliyeti fazla olan malzemelerin kırılma tokluğu değeri yüksektir. Genelde takviye oranının artması ile tokluk düşmektedir. Partikül boyutunun büyük olması da kırılma tokluğunu arttırır [8]. Ayrıca metal matrisli kompozitlerde süneklik takviyesiz alaşıma göre azalmaktadır. Takviye hacim oranı arttıkça da süneklik düşer ve yüzde uzama değeri azalır. Sünekliği optimum seviyeye getirmek için ince tane boyutu, homojen takviye dağılımı ve iyi ara yüzey dayanımı gerekmektedir [7].

Uygulama alanları göz önüne alındığında özellikle havacılık endüstrisi için en önemli mekanik özelliklerden birisi de yorulmadır. Malzemeler statik dayanımından daha düşük ve tekrarlanan gerilmeler altında çalışmış olsalar bile belirli bir çevrim sayısı sonunda malzemede yorulma hasarı olarak adlandırılan değişmeler oluşmaktadır. Havacılık ve denizcilik alanında geçmişte birçok kazaya sebep olduğu için sürekli yorulma olayı üzerinde çalışılmaktadır. Yorulma olayında birçok etken rol oynamaktadır. Bunlar çevresel etkilerden, malzemenin üretim sürecinden veya gerilme koşullarından kaynaklanmaktadır. Bu karmaşık olayı incelemek ve tanımak olası birçok yorulma kırılması ve kazayı önlemek açısından önemlidir [9]. Yorulma olayının incelenmesi 19. yy ortalarında ilk kez Wöhler tarafından yapılmıştır. Teknolojik gelişmeler hız kazandıkça bu olayın ne kadar önemli olduğu anlaşılmıştır. Havacılık ve otomobil endüstrisi başta olmak üzere, makine parçalarındaki mekanik hasarların \%90’1 yorulma sebebiyle oluşmaktadır [10].

Yorulmadan kaynaklanan kırılmalar çevrimsel gerilmeler sonucu oluşarak, çatlak başlangıcı, çatlağın kritik boyuta ilerlemesi ve kırılmanın meydana gelmesi şeklinde gerçekleşir [11]. Çatlağın başladığı noktalar genelde, delikler, zayıf kaynak veya çentikler gibi iç gerilmelerin toplandığı yerlerdir. Çevrimsel yüklerin neden olduğu dislokasyonlar ve kayma bantlarının oluşturduğu gerilme yığılma noktaları çatlağın başladığı yerlerdendir [12]. Yorulma-çatlak ilerleme mekanizması incelemelerinde şu faktörlerin yer aldığı görülmektedir [13]. Malzemenin kristalografik doğası, boşluk ve kalıntılarda çatlak başlangıc1, mikro çatlaklar, çatlak büyüme bariyerleri, çatlak ilerleme eşik değeri, yüzeyin etkileri, makro boyutta çatlak ilerlemesi, çevrenin etkileri ve tekrarlı gerilmelerdir. Ayrıca malzemenin üzerine gelen aşırı yüklerin de çatlak ilerlemesini etkilediği yapılan çalışmalarda görülmektedir

Metal matrisli kompozit malzemelerin üretim yöntemlerinden birisi de toz metalürjisidir (TM). Bu yöntem temel olarak metal veya metal alaşımı tozları ile takviye seramik tozlarının karıştırılıp preslenmesi ve sinterlenmesi aşamalarından oluşmaktadır. TM tekniğiyle bir kalıpla birden fazla malzeme seri üretimle üretilebilir. Bu nedenle üretim maliyetleri düşüktür. Diğer yöntemlerle imalatı ve şekillendirilmesi zor olan birçok malzeme TM tekniğiyle kolay bir şekilde üretilebilir. Geniş uygulama alanı ve kullanılabilecek malzeme türünün çok fazla olması TM tekniğinin avantajlarındandır. 


\section{Malzeme ve Yöntem}

\subsection{Malzeme}

$\mathrm{Bu}$ çalışmada toz metalürjisi yöntemiyle alüminyum esaslı SiC takviyeli metal matrisli kompozitlerin üretimi gerçekleştirilmiştir. Üretim için havacılık endüstrisinde yaygın olarak yer bulan AA2024 alüminyum alaşımı tercih edilmiştir. Alaşımın içeriği Tablo 1'de gösterilmiştir. Kullanılan AA2024 serisi alüminyum tozlarının ortalama boyutu 40 mikrondur. Seramik takviye malzemesi olarak ortalama boyutu 7 mikron olan SiC tozu kullanılmıştır.

Tablo 1. AA2024 alaşımının içeriği (ağırlıkça \%)

\begin{tabular}{|l|c|c|c|c|c|c|c|c|}
\hline \multicolumn{1}{|c|}{ Oran $(\%)$} & $\mathbf{S i}$ & $\mathbf{F e}$ & $\mathbf{C u}$ & $\mathbf{M g}$ & $\mathbf{M n}$ & $\mathbf{C r}$ & $\mathbf{Z n}$ & $\mathbf{T i}$ \\
\hline Minimum & - & - & 3,8 & 1,2 & 0,3 & - & - & - \\
\hline Maksimum & 0,5 & 0,5 & 4,9 & 1,8 & 0,9 & 0,1 & 0,25 & 0,15 \\
\hline
\end{tabular}

\subsection{Toz Metalurjisi ile Bilet Üretimi}

AA2024 alaşımı ve SiC tozu kullanılarak ekstrüze edilmek üzere biletler üretilmiştir (Şekil 3). Hacimce \%5 SiC içeren kompozit ve takviyesiz AA2024 alaşım olmak üzere 2 farklı karışım kullanılmıştır. Hacimce \%5 SiC içeren karışım için karıştırma işlemi 4 saat süreyle çelik bilyeler de kullanılarak 3 eksenli karıştırıcıda yapılmıştır. Elde edilen tozlar tek yönlü hidrolik preste preslenerek $\varnothing 50$ × 60 mm ölçülerinde silindirik bloklar edilmiştir (Şekil 2.). Bu işlem $600^{\circ} \mathrm{C}$ sıcaklıkta ve 40 bar basınçta 45 dakika süreyle yapılmıştır. Üretim için sıcak iş takım çeliğinden üretilen kalıp ve pul kullanılmıştır.
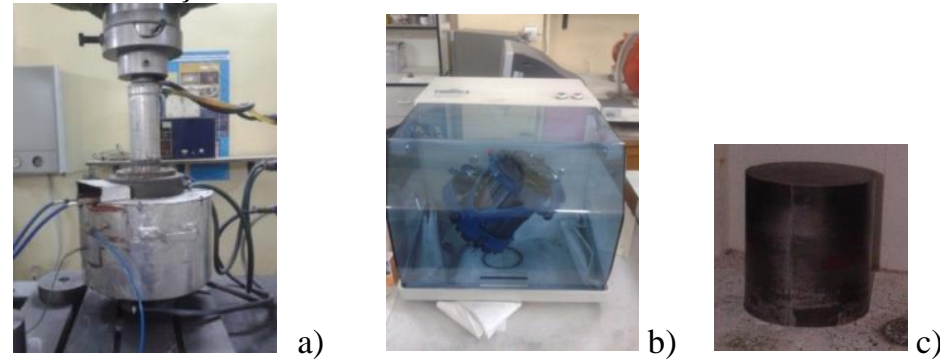

Şekil 2. Bilet üretimi; a) hidrolik pres b) karıştırıcı c) bilet

\subsection{Biletlerin Ekstrüzyonu}

Üretilen biletlere ikincil işlem olarak ekstrüzyon uygulanmış ve genişliği 40 mm kalınlığ 5 mm olan plakalar elde edilmiştir. Bu işlem için ekstrüzyon oranı aşağıdaki hesaplamaya göre 10:1 olarak belirlenmiştir.

R: ekstrüzyon oranı

Ab: bilet kesit alan $1=\pi r^{2}=3,14 \times 25^{2}=1963,5$

An : numune kesit alanı $=5 \times 39=195$

$\mathrm{R}=\mathrm{Ab} / \mathrm{An}=1963,5 / 195=10,07$ 
Ekstrüzyon oranına uygun olarak kalıp tasarlanmış ve sıcak iş çeliğinden üretimi yaptırılmıştır (Şekil 4). Hazırlık aşamasında bilet ilk önce $500^{\circ} \mathrm{C}$ 'de ayarlanmış firında $30 \mathrm{dk}$ süre ile bekletilmiştir. Bu arada kalıp, kalıp taşıyıcı ve pul grafitlenerek hazırlanmıştır. Fırından çıkarılan bilet yine $500^{\circ}$ C'ye getirilmiş ısıtıcı kovanın içine yerleştirilmiş ve pres üzerinde ekstrüzyon düzeneği kurulmuştur (Şekil 3.). Yaklaşık 80 bar basınçta malzemenin yumuşayarak kalıbın şeklini almasıyla plakalar elde edilmiştir.

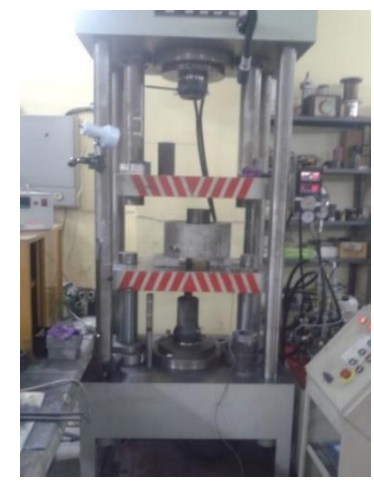

\section{4 Çekme ve Yorulma Numunesi Hazırlama}

Şekil 3. Hidrolik pres ve ekstrüzyon düzeneği

7ASTM E8 standartlarına göre çekme numunesinin ve ASTM E647 standartlarına göre de CT (Compact Tension) yorulma numunesinin çizimleri yapılmıştır. Ekstrüzyon sonucu elde edilen plakalardan bu çizimlere göre tel erezyon yöntemiyle çekme ve CT yorulma numuneleri çıartılmıştır (Şekil 4-5).
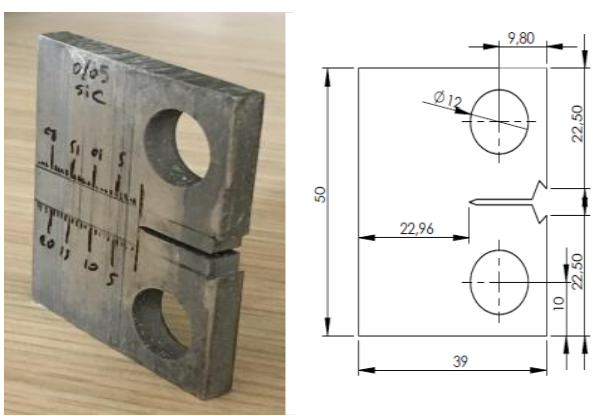

Şekil 4. ASTM 647 Standartlarına göre üretilen CT yorulma numunesi ve çizimi
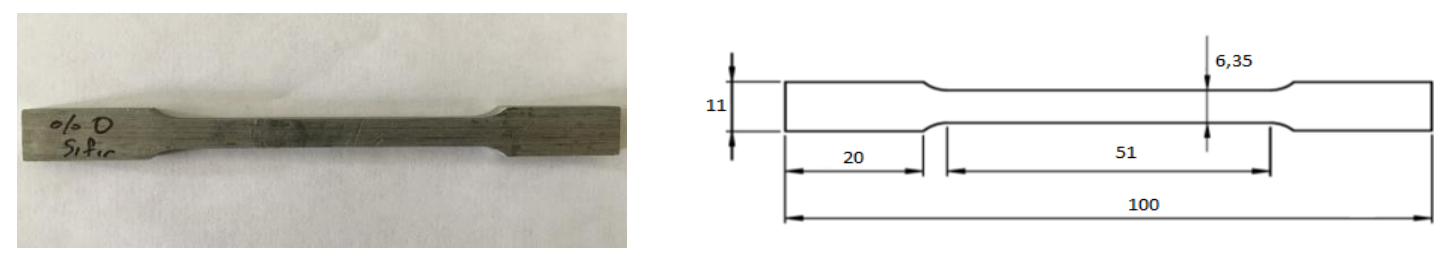

Şekil 5. ASTM E8 standartlarına göre üretilen çekme numunesi ve çizimi 


\section{5 Çekme Deneyi}

ERÜ Teknoloji Araştırma ve Uygulama Merkezi (TAUM) bünyesinde bulunan deney cihazı kullanılmıştır (Şekil 6). 3 adet \%5 SiC takviyeli kompozit ve 2 adet takviyesiz AA2024 alaşımından üretilen numunelere çekme testi uygulanmıştır.

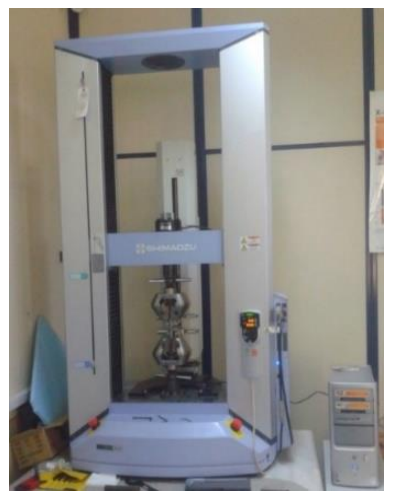

\subsection{Yorulma Deneyi}

Şekil 6. Çekme deneyi cihazı ve düzeneği

Abdullah Gül Üniversitesi (AGÜ) İnşaat Mühendisliği bölümü bünyesinde bulunan INSTRON 8801 marka yorulma deney cihazı kullanılarak yorulma deneyleri yapılmıştır (Şekil 8-9). Sabit genlikli yükleme ve tek aşırı yüklerin uygulandığı çalışmada 8 adet numunenin testi yapılmıştır. Yapılan deneylerin parametreleri Tablo 2'de gösterilmiştir. Tek aşırı yük kullanılan deneyler için şematik yük-zaman grafiği Şekil 7’ de gösterilmiştir.

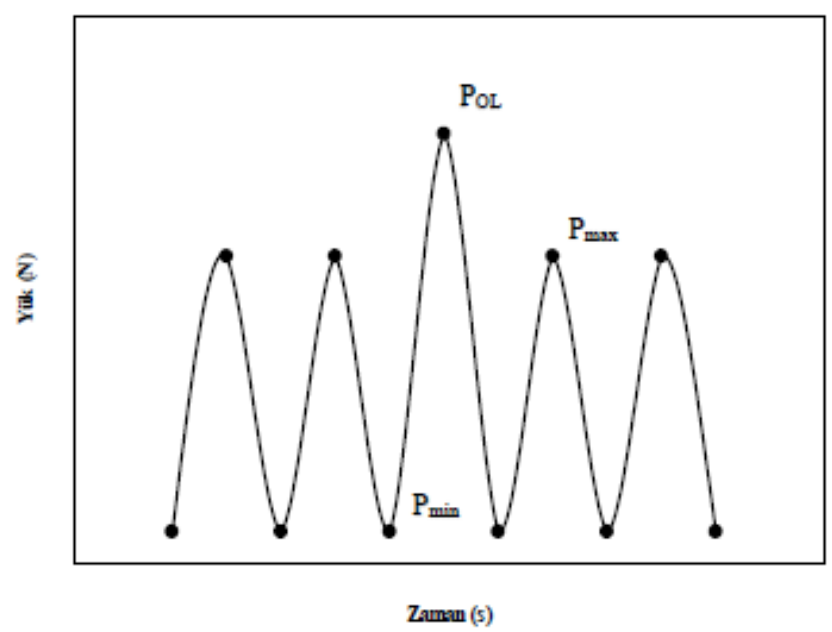

Şekil 7. Sabit genlikli yorulma deneyinde yük-zaman grafiğinin şematik gösterimi 
Tablo 2. Yorulma deneylerinde kullanılan numuneler ve uygulanan yükler

\begin{tabular}{|l|l|l|l|l|}
\hline $\begin{array}{l}\text { Matris } \\
\text { Malzemesi }\end{array}$ & $\begin{array}{l}\text { SiC } \text { Takviye } \\
\text { Oranı }\end{array}$ & $\begin{array}{l}\text { Maks. } \\
\text { Yük }\end{array}$ & $\begin{array}{l}\text { Min. } \\
\text { Yük }\end{array}$ & $\begin{array}{l}\text { Tek Aşır1 Yük } \\
\text { Oranı }\end{array}$ \\
\hline AA2024 & Takviyesiz & $1400 \mathrm{~N}$ & $140 \mathrm{~N}$ & - \\
\hline AA2024 & Takviyesiz & $1400 \mathrm{~N}$ & $140 \mathrm{~N}$ & 1.4 \\
\hline AA2024 & Takviyesiz & $1400 \mathrm{~N}$ & $140 \mathrm{~N}$ & 1.6 \\
\hline AA2024 & $\% 5$ & $1400 \mathrm{~N}$ & $140 \mathrm{~N}$ & - \\
\hline AA2024 & $\% 5$ & $1400 \mathrm{~N}$ & $140 \mathrm{~N}$ & 1.25 \\
\hline AA2024 & $\% 5$ & $1400 \mathrm{~N}$ & $140 \mathrm{~N}$ & 1.4 \\
\hline AA2024 & $\% 5$ & $1400 \mathrm{~N}$ & $140 \mathrm{~N}$ & 1.6 \\
\hline AA2024 & $\% 5$ & $1400 \mathrm{~N}$ & $140 \mathrm{~N}$ & 1.75 \\
\hline
\end{tabular}

Yorulma deneyinde tekrarlı yük frekansı $30 \mathrm{~Hz}$ olarak belirlenmiştir. Cihaza ait yazılıma deney parametreleri girilmiştir. Çatlak boyu ölçümleri dijital mikroskop yardımıyla yapılmıştır. Mikroskobun fotoğraf ve video çekme imkanı veren özellikleriyle çatlak ilerlemesi takip edilmiştir. Bütün numunelerde çatlak boyu $3.7 \mathrm{~mm}$ olduğu anda tek aşırı yükler uygulanmıştır. Ayrıca enstansometre aracılığıyla cihaza ait yazılım, çene pozisyonu, yük, çevrim sayısı, çatlak ağzı açıklık mesafesi gibi verileri otomatik olarak kaydetmiştir.

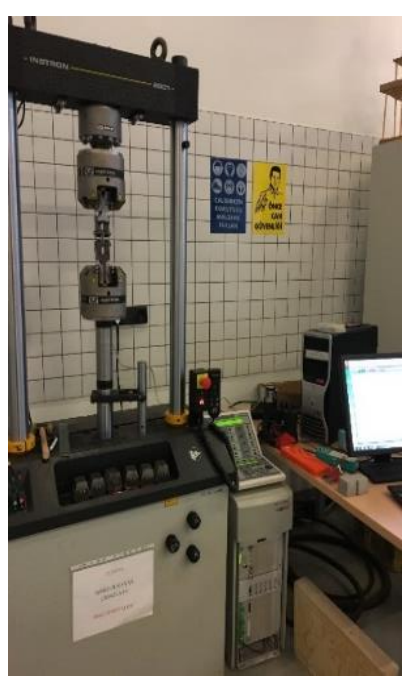

Şekil 8. INSTRON 8801 yorulma testi cihazı 


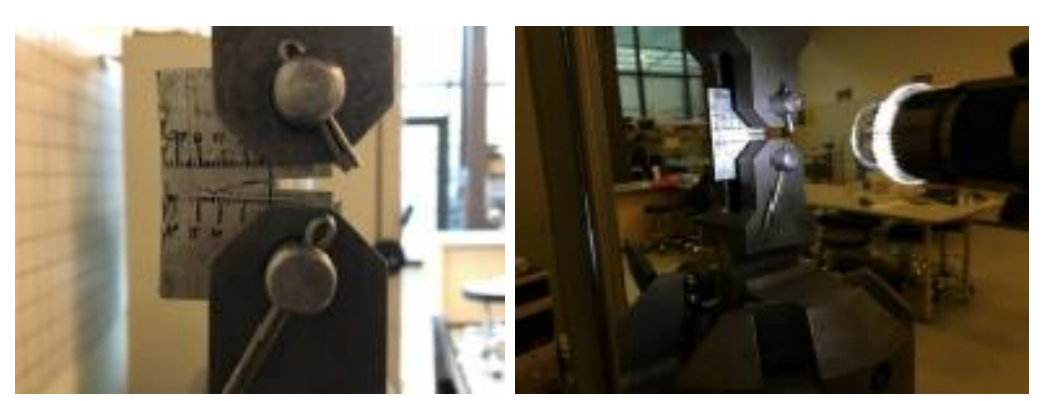

Şekil 9. INSTRON 8801 yorulma test cihazı ve CT yorulma numunesinin test cihazına bağlanması

\section{Bulgular ve Tartışma}

\section{1 Çekme Deneyi Sonuçları}

Al 2024 takviyesiz alaşım ve \%5 SiC takviyeli MMK numunelere ait çekme deneyi sonuçlarına göre gerilme- yüzde uzama grafikleri Şekil 10’ da gösterilmiştir.
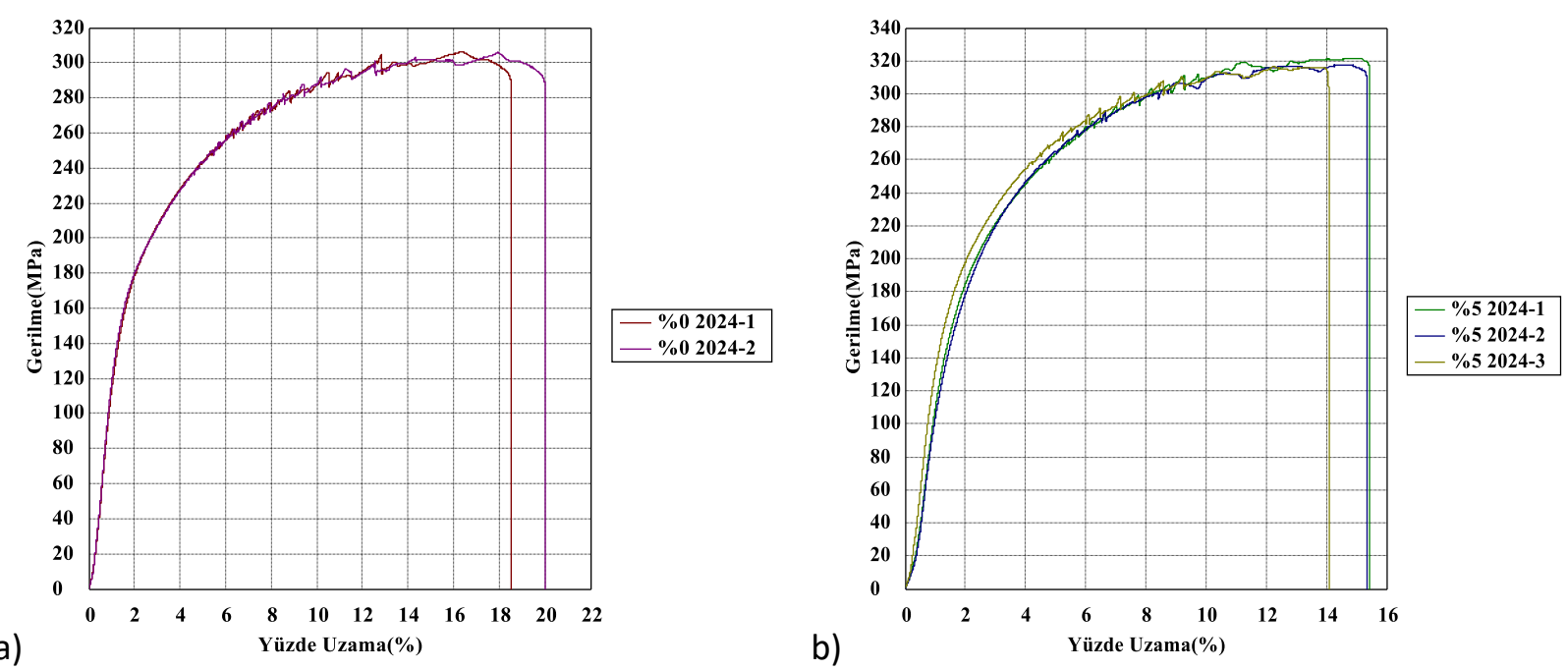

Şekil 10. Gerilme-Yüzde Uzama grafiği a) Takviyesiz alüminyum alaşım b)\%5 SiC takviyeli MMK

Gerilme-yüzde uzama grafiklerine bakıldığında \%5 SiC takviyesinin maksimum gerilme değerini arttırdığı ve yüzde uzama değerini azalttığı görülmektedir.

\subsection{Yorulma Deneyi Sonuçları}

Şekil 11' de Al 2024 takviyesiz alaşım numunelere ait sabit genlikli ve iki farklı oranda (1.4 ve 1.6 ) aşırı yük uygulanan yorulma deneylerinde gözlenen çatlak boyu- çevrim sayısı grafikleri ve \%5 $\mathrm{SiC}$ takviyeli MMK numunelere ait sabit genlikli ve dört farklı oranda $(1.25,1.4,1.6$ ve 1.75$)$ tek aşırı yük uygulanan yorulma deneylerinde gözlenen çatlak boyu- çevrim sayısı grafikleri gösterilmektedir. 


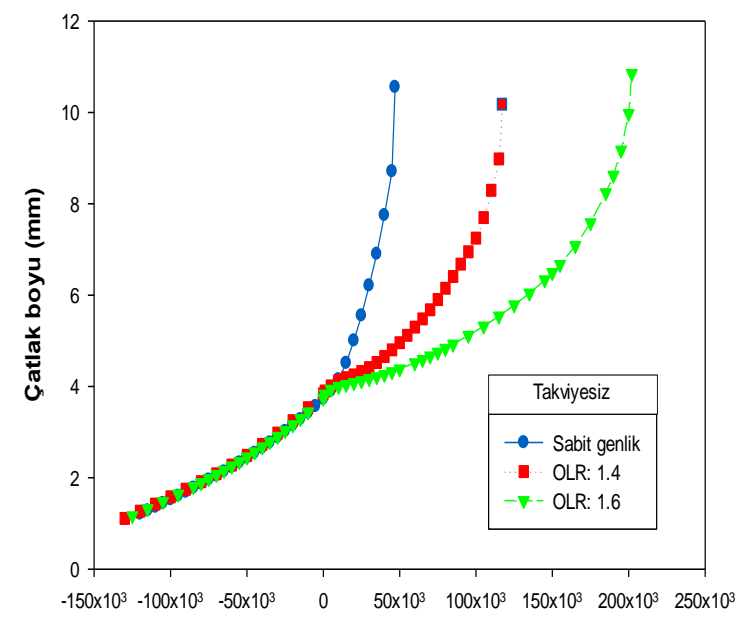

a)

Aşıı yükten itibaren çevrim sayısı ( $\left.\mathrm{N}-\mathrm{N}_{\mathrm{OL}}\right)$

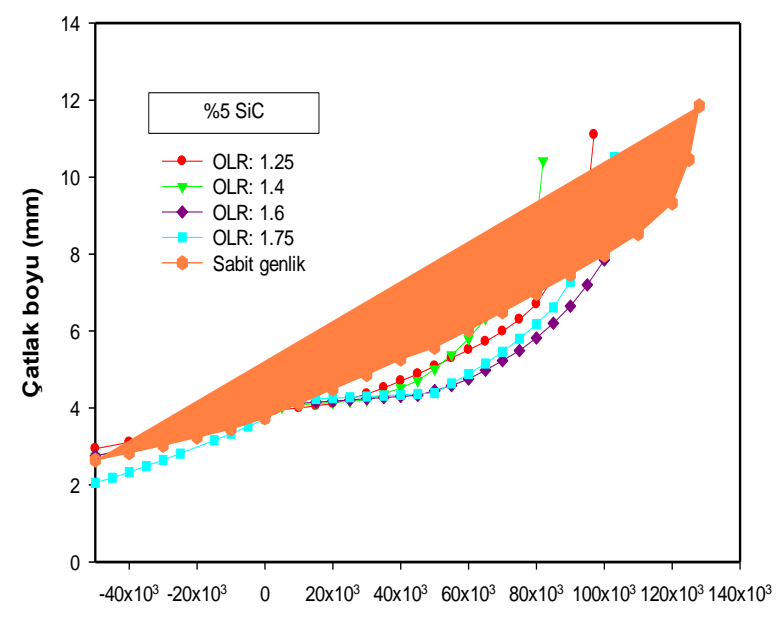

b)

Aşırı yükten itibaren çevrim sayısı ( $\left.\mathrm{N}-\mathrm{N}_{\mathrm{OL}}\right)$

Şekil 11. Tek aşırı yük uygulanan yorulma deneylerinde gözle nen çatlak boyu- çevrim sayısı grafikleri a) Takviyesiz alüminyum alaşımı, b) \%5 SiC takviyeli MMK

Tablo 3-4' de yorulma testlerinden elde edilen veriler yer almaktadır.

Tablo 3. Takviyesiz alüminyum alaşım numunelere ait yorulma testi verileri

\begin{tabular}{|l|l|l|l|}
\hline $\begin{array}{l}\text { Tek aşırı yük oranı } \\
(\mathrm{OLR})\end{array}$ & $\begin{array}{l}\text { Toplam çevrim sayısı } \\
(\mathrm{N})\end{array}$ & $\begin{array}{l}\text { Gecikme çevrim sayısı } \\
\mathrm{N}_{\mathrm{D}}\end{array}$ & $\begin{array}{l}\text { Aşırı yük sonrası } \\
\text { çevrim sayısı (N- } \\
\left.\mathrm{N}_{\mathrm{OL}}\right)\end{array}$ \\
\hline- & 437000 & - & - \\
\hline 1.4 & 525000 & 30000 & 125000 \\
\hline 1.6 & 628000 & 60000 & 208000 \\
\hline
\end{tabular}

Tablo 4. \%5 SiC takviyeli MMK numunelere ait yorulma testi verileri

\begin{tabular}{|l|l|l|l|}
\hline $\begin{array}{l}\text { Tek aşırı yük oranı } \\
(\text { OLR })\end{array}$ & $\begin{array}{l}\text { Toplam çevrim sayısı } \\
(\mathrm{N})\end{array}$ & $\begin{array}{l}\text { Gecikme çevrim sayıs1 } \\
\mathrm{N}_{\mathrm{D}}\end{array}$ & $\begin{array}{l}\text { Aşırı yük sonras1 } \\
\text { çevrim sayıs1 }\end{array}$ \\
\hline- & 608000 & - & - \\
\hline 1.25 & 507000 & 15000 & 97000 \\
\hline 1.4 & 525000 & 25000 & 88000 \\
\hline 1.6 & 535000 & 35000 & 110000 \\
\hline 1.75 & 490000 & 50000 & 103000 \\
\hline
\end{tabular}


Çatlak boyu- çevrim sayısı grafiklerinin tümünde görüldüğü üzere gözle görülebilen çatlaklar belirli bir çevrim sayısından sonra oluşmaktadır. Çatlak oluştuktan sonra yüklemeye devam edildikçe çatlak boyu hızlanarak artmaktadır. Çatlak boyu arttıkça çatlak ilerlemesinin hızlandığı görülmektedir. Tek aşırı yükler uygulandığı anda çatlak boylarında ani bir artışın olduğu gözlemlenmektedir. Tek aşırı yük oranı arttıkça bu anlık hızlanma da artmıştır. Bu anlık hızlanmadan sonra çatlak ilerlemesinin bir süre yavaşladığı yani çatlağın geciktiği görülmektedir. Tek aşırı yük oranının artması çatlak ilerleme gecikmesini artırmaktadır. Şekil 12'de farklı tek aşırı yüklerin çatlak ilerleme hızına etkisini gösteren çatlak ilerleme hızı grafikleri vardır.
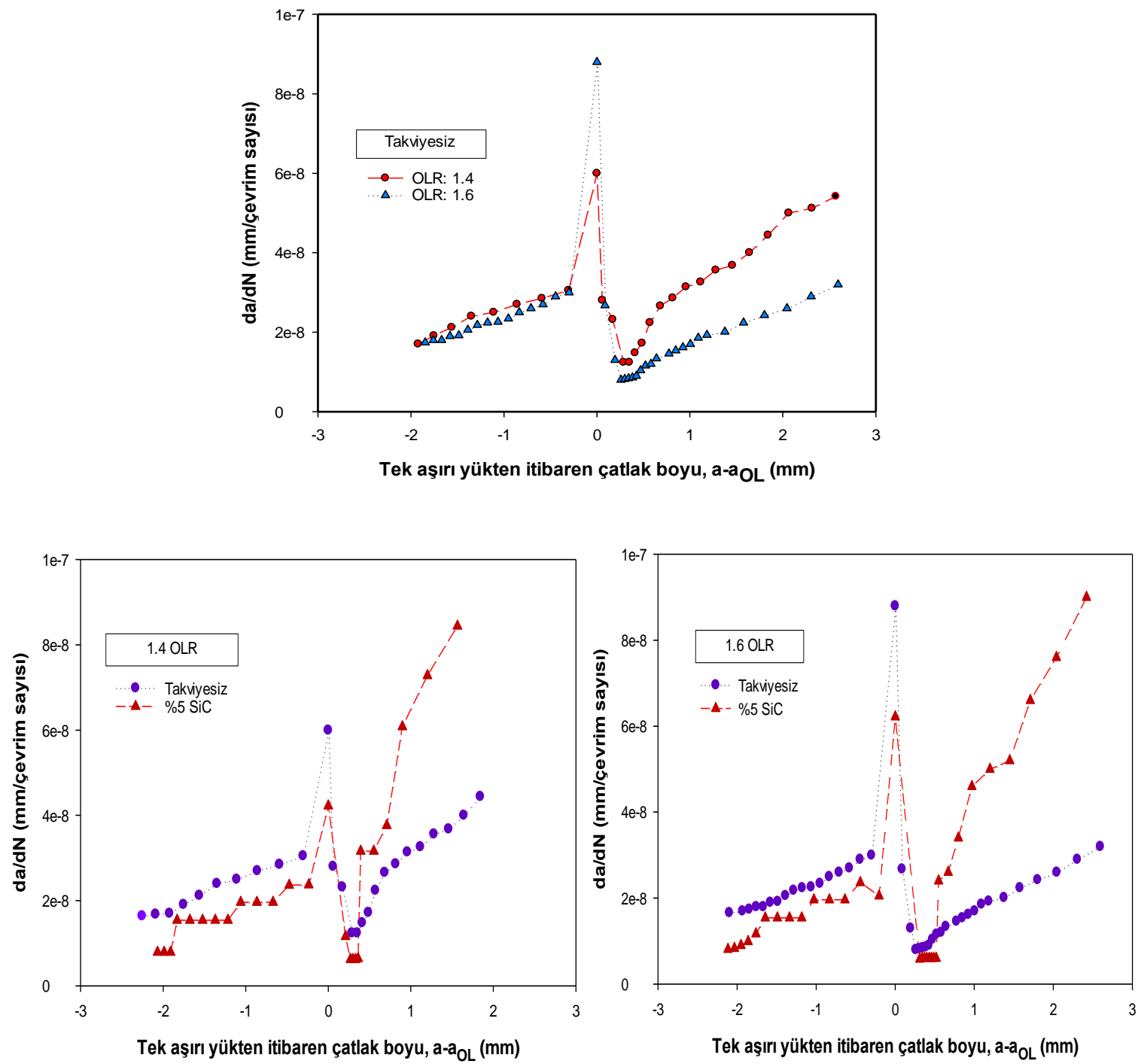

Şekil 12. Tek aşırı yüklerin ve \%5 SiC takviyesinin çatlak ilerleme hızına etkisini gösteren da/dN-çatlak boyu grafikleri 
Tablo 5. \%5 SiC takviyesinin ve farklı tek aşırı yüklerin yorulma çatlak ilerlemesindeki gecikmeye etkisi

\begin{tabular}{|c|c|c|}
\hline $\begin{array}{c}\text { Tek aşırı yük oranı } \\
(\text { OLR) }\end{array}$ & \multicolumn{2}{|c|}{ Gecikme çevrim sayıs1 $\mathrm{N}_{\mathrm{D}}$} \\
\cline { 2 - 3 } & TAKVIYESİZ & $\% 5 \mathrm{SiC}$ \\
\hline 1.4 & 30000 & 25000 \\
\hline 1.6 & 60000 & 30000 \\
\hline
\end{tabular}

1.4 ve 1.6 oranında tek aşırı yükün uygulandığı deney sonuçlarına bakıldığında, aşırı yükün uygulandığı noktaya kadar takviyesiz alaşım daha hızlı bir çatlak ilerlemesine sahiptir. Çatlak ilerleme hızındaki artış kısmen düzenlidir. MMK numunede daha düzensiz ve genel olarak daha yavaş bir ilerleme görülmektedir. Tek aşırı yükler uygulandğında her iki deneyde ani çatlak ilerleme hızı artışı görülmektedir. Takviyesiz numunede artış daha fazladır. Yine her iki deney içinde tek aşırı yükün uygulanmasından 3 çevrim sayısı sonra minimum çatlak ilerleme hızları elde edilmiştir. MMK numunelerde minimum çatlak ilerleme hızı daha düşüktür. İki numunenin her iki tek aşırı yük uygulanan deneylerinde minimum çatlak ilerleme hızından sonra çatlağın geciktiği görülmektedir. Aynı tek aşırı yüklerin kullanıldığı deneylerde gecikme çevrim sayısının takviyesiz numunelerde \%5 SiC MMK numunelere göre daha fazla olduğu Tablo 5'te görülmektedir. Çatlak büyüme hızının takviyesiz alaşım numunesi deneyinde $\% 5 \mathrm{SiC}$ MMK deneylerine göre daha fazla olduğu görülmektedir. Takviyesiz alaşımın kullanıldığı deneyde kısmen düzenli bir hız artışı görülmesine rağmen $\% 5 \mathrm{SiC}$ numunesinde bazı noktalarda hız artışının daha az olduğu görülmektedir.

\section{Sonuçlar}

Çekme deneylerinde gerilme- yüzde uzama grafiklerine bakıldığında $\mathrm{SiC}$ takviyesinin maksimum gerilmeyi arttırdı̆̆ı, yüzde uzamayı azalttı̆̆ görülmektedir. Buradan $\mathrm{SiC}$ takviyesinin tokluğu azalttığı ve mukavemeti arttırdığı sonucuna ulaşılmaktadır.

Sabit genlikli yorulma deneylerinin sonuçları incelendiğinde $\% 5 \mathrm{SiC}$ takviyesinin yorulma çatlak ilerleme direncini arttırdığı gözlemlenmektedir. Malzemenin rijitliğini artıran SiC karbür parçacıklarının çatlak ilerleme hızını yavaşlattığı görülmektedir. Buna matris-takviye ara yüzey ayrılmaları parçacık kırılması gibi mekanizmaların da etkili olduğu sonucuna varılmaktadır. Takviyesiz alaşım numunelerde çatlak yolu kısmen düzgün olsa da $\mathrm{SiC}$ takviyeli numunelerde çatlağın daha kavisli bir yol izlediği görülmektedir. Buna sert partikül malzemesinin çatlak ucunu etkilemesi sebep olmaktadır.

Tek aşırı yükün yorulma çatlak ilerleme davranışına etkisi ele alındığında, tek aşırı yüklerin çatlağı yavaşlattığı ve bir süre ilerlemesini geciktirdiği sonucuna açık bir şekilde varılmaktadır. Tek aşırı 
yük oranı arttıkça yavaşlamaya olan etkisi ve gecikme çevrim sayısı artmaktadır. Aynı tek aşırı yük uygulanan takviyesiz alaşım ve SiC takviyeli MMK numunelerin deney sonuçlarına bakıldığında MMK'lerde çatlak ilerleme gecikmesinin daha az olduğu görülmektedir. Tek aşırı yüklerin uygulandığı anda malzemelerde çatlak ilerleme hızının anlık olarak arttığı ve çatlağın aniden büyüdüğü görülmektedir. Bu artış tek aşırı yük oranı arttıkça artmaktadır. Çatlak ilerlemesindeki ani hızlanma \%5 $\mathrm{SiC}$ takviyesiyle azalmaktadır.

\section{Referanslar}

[1] Şahin, Y., 2006. Kompozit Malzemelere Giriş. Seçkin Yayıncılık, 424

[2] Özarslan, B.S., 2004. Alüminyum Esaslı SiC Partikül Takviyeli Metal Matrisli Kompozit Malzemelerin Mekanik Özelliklerinin İncelenmesi. İstanbul Üniversitesi, Yüksek Lisans Tezi, İstanbul, 123

[3] Mutlu, İ., 1996. Alüminyum Matriksli Metal Kompozit Malzemelerin Üretilmesi. Dumlupınar üniversitesi, Yüksek Lisans Tezi, Kütahya, 4

[4] Gül, F., 1999. Döküm Yoluyla Alüminyum Temelli Parçacık Takviyeli Kompozit Geliştirme. Marmara Üniversitesi, Doktora Tezi, İstanbul, 173

[5] Buytoz, S., Y1ldırım, M., 2002. Metal matrisli kompozit malzemelerin üretim yöntemleri, 349357. 9.Denizli Malzeme Sempozyumu, 8-9-10 Mayıs, Pamukkale Üniversitesi, 536

[6] Ilgaz, M.U., 1997. Basınçlı Döküm Yöntemiyle Üretilen Seramik Partikül Takviyeli Al-Si Esaslı Metal Matriksli Kompozit Malzemelerin Mekanik Özellikleri. İstanbul Üniversitesi, Yüksek Lisans Tezi, İstanbul, 76

[7] Evans, A.G., Hutchinson, J.V., McMeeking, R.M., 1991. Stress-strain behaviour metal matrix composites with discontinuous reinforcements. Scripta metallurgica et materialia, 25: 3-8

[8] Kamat, S.V., Hirth, J.P., Mehrabian, R., 1989. Mechanical properties of particulate reinforced aluminum matrix composites. Acta metallurgica, 37: 2395-2402

[9] Onaran, K., 2014. Malzeme Bilimi. Bilim ve Teknik, İstanbul, 384

[10] Kayal1, E.S., 1996. Metalik Malzemelerin Mekanik Deneyleri. İ.T.Ü., İstanbul, 181

[11] Da Costa, C.E., Velasco, F. Torralba, M.J. Mechanical, intergranular corrosion, and wear behaviour of aluminum-matrix composite materials reinforcedwith nickel aluminides. Metallurgical and materials transactions A, 33(11): 3541-3553

[12] Yayla, P., 2007. Kırılma Mekaniği. Çağlayan Kitabevi, İstanbul, 229 
[13] Schijve, J., 2009. Fatigue of Structures and Materials. Springer, 621

[14] Chawla N., Ganesh, V.V., 2010. Fatigue crack growth of SiC particle reinforced metal matrix composites. International journel of fatigue, 32(5): 856-863

[15] Anderson, T.L., 2005. Fracture Mechanics: Fundamentals and Applications. CRC Press, 640 
Y. CAM et al./ISITES2019 SanliUrfa - Turkey 